\title{
Capital Adequacy Ratio, Loan to Deposit Ratio, Ukuran Perusahaan dan Return On Assets dengan Non Performing Loan sebagai Variabel Pemoderasi
}

\author{
Made Diah Dianti Anggawulan' \\ Fakultas Ekonomi dan Bisnis \\ Universitas Udayana, Indonesia
}

\author{
I Made Sadha Suardikha² \\ Fakultas Ekonomi dan Bisnis \\ Universitas Udayana, Indonesia
}

\section{ABSTRAK}

Penelitian ini memiliki tujuan yaitu menguji bagaimana CAR, LDR, dan ukuran perusahaan berpengaruh pada ROA dengan NPL sebagai variabel moderasi. Lokasi penelitian dilakukan pada Bursa Efek Indonesia (BEI) melalui situs resminya www.idx.co.id dengan populasi 43 perusahaan yang terdapat di Bursa Efek Indonesia tahun 2017. Teknik purposive sampling digunakan dalam penentuan sampel pada penelitian ini, sehingga didapatkan sampel penelitian sebanyak 39 perbankan. Analisis data yang dipergunakan yaitu uji MRA (Moderated Regression Analysis). Menurut hasil analisa ditemukan bahwa CAR, LDR, NPL, serta ukuran perusahaan tidak memiliki pengaruh terhadap ROA. NPL tidak dapat memoderasi CAR, LDR, dan ukuran perusahaan terhadap ROA.
\end{abstract}

Surel : diahdiant@gmail.com

Kata Kunci: CAR; LDR; NPL; ROA; Ukuran Perusahaan.

\section{Capital Adequacy Ratio, Loan to Deposit Ratio, Company Size and Return On Assets with Non Performing Loans as Moderating Variables}

\section{ABSTRACT}

This study aims to examine how CAR, LDR, and firm size influence ROA with NPL as a moderating variable. The location of the study was conducted at the Indonesia Stock Exchange (IDX) through its official website www.idx.co.id with a population of 43 companies that are on the Indonesia Stock Exchange in 2017. Purposive sampling technique was used in the determination of the sample in this study, so as to obtain a research sample of 39 banking. Analysis of the data used is the MRA (Moderated Regression Analysis) test. According to the result of the analysis it was found that CAR LDR, NPL, and firm size do not have an influence on ROA. NPL cannot moderate CAR, LDR, and firm size to ROA.

Keywords: $\quad$ CAR; LDR; NPL; ROA; Firm Size.

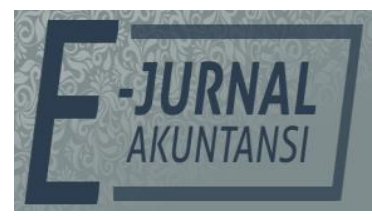

e-ISSN 2302-8556

Vol. 31 No. 1

Denpasar, Januari 2021 Hal. 130-141

DOI:

10.24843/EJA.2021.v31.i01.p10

PENGUTIPAN: Anggawulan, M.D.D., \& Suardikha, I M.S. (2021).

Capital Adequacy Ratio, Loan to Deposit Ratio, Ukuran

Perusahaan dan Return On Assets dengan Non

Performing Loan sebagai

Variabel Pemoderasi. EJurnal Akuntansi, 31(1), 130-

141

RIWAYAT ARTIKEL:

Artikel Masuk:

3 Februari 2020

Artikel Diterima:

1 Januari 2021

Artikel dapat diakses : https://ojs.unud.ac.id/index.php/Akuntansi/index 


\section{PENDAHULUAN}

Pada era globalisasi seperti saat ini, ada beberapa orang bekerja sebagai pegawai negeri, pegawai swasta, driver online, ada pula yang membuka suatu usaha entah itu sebagai pekerjaan utama ataupun pekerjaan sampingan mereka. Selain membuka usaha, ada pula yang melakukan investasi agar mampu mendapatkan penghasilan. Ketika ingin menjalankan suatu kegiatan usaha, kita pasti membutuhkan modal agar terciptanya suatu usaha tersebut. Dalam hal ini masyarakat akan meminjam modal melalui jasa kredit yang dimiliki oleh bank. Kepercayaan masyarakat dalam menyimpan maupun meminjam dana di bank sangat dipengaruhi oleh informasi yang diperolehnya mengenai kualitas dan kinerja bank yang bersangkutan dengan salah satu indikatornya adalah menilai tingkat kesehatan bank. Jika bank dalam keadaan sehat, maka keadaan tersebut perlu untuk dipertahankan. Jika bank dalam keadaan kurang atau tidak sehat, maka perlu adanya sikap atau tindakan dalam memperbaiki keadaan tersebut karena melalui tingkat kesehatan bank akan dapat menunjukkan bagaimana kinerja bank tersebut.

Salah satu yang dapat digunakan dalam mengukur kinerja suatu bank adalah dengan melihat profitabilitas bank melalui laporan keuangan bank tersebut. Pada penelitian ini profitabilitas diproksikan dengan Return On Assets (ROA) karena ROA memfokuskan kemampuan perusahaan untuk memperoleh laba dalam operasi perusahaan, sedangkan ROE hanya mengukur return yang diperoleh dari investasi pemilik perusahaan dalam bisnis bank.

Rasio profitabilitas bank pada tahun 2018 dinilai akan memasuki periode pemulihan setelah penurunan yang terjadi sepanjang 2017. Walaupun memasuki masa recovery atau pemulihan, tetapi masih sulit untuk meletakkan rasa optimis bahwa tingkat profitabilitas yang salah satunya tercermin dari rasio return of assets (ROA). Tingkat profitabilitas yang rendah dapat dipengaruhi oleh kecukupan modal yang dimiliki oleh perbankan (Hendra, 2016).

Salah satu faktor suatu perusahaan mampu beroperasi yaitu dengan memiliki modal yang cukup dalam membiayai kegiatan operasional perusahaan tersebut. Modal yang dimiliki tersebut juga dapat digunakan dalam menanggung risiko beserta kerugian yang dialami perbankan. Kecukupan modal suatu bank mempengaruhi bank dalam beroperasi ataupun tidak, serta berkaitan dengan dipercaya atau tidaknya suatu bank oleh pengguna jasa bank.

Selain kecukupan modal, profitabilitas juga dapat dipengaruhi oleh adanya aktivitas penyaluran kredit (Trisna, 2017). Bank berperan sebagai lembaga keuangan yang tidak lepas dari permasalahan kredit karena kredit adalah sumber penghasilan pada sector perbankan. Semakin bank sering menyalurkan kredit, maka pendapatan bunga bank pun bertambah. Bertambahnya pendapatan bunga tersebut akan berdampak pada peningkatan profitabilitas.

Terdapat faktor lain yang mampu mempengaruhi tingkat profitabilitas (ROA) yaitu ukuran perusahaan (Purba, 2018). Kemampuan manajemen perusahaan akan terlihat baik apabila mampu memutar aset yang dimilikinya dalam rangka memperoleh laba. Pada beberapa penelitian terdahulu, besarnya aset suatu perusahaan menentukan besar kecilnya perusahaan. Perusahaan harus mampu mengelola dan memanfaatkan aset tersebut sebaik-baiknya sehingga menghasilkan keuntungan atau laba bagi perusahaan. Sebuah perusahaan yang 
termasuk dalam perusahaan besar dan saham yang tersebar luas memiliki kekuatan tersendiri dalam menghadapi masalah bisnis. Perusahaan besar juga cenderung memiliki kemampuan menghasilkan laba lebih tinggi karena usaha tersebut didukung oleh aset yang besar, sehingga kendala pada perusahaan yang berhubungan dengan aset bisa teratasi. Oleh karena itu ukuran perusahaan merupakan salah satu faktor yang menentukan kemampuan perusahaan menghasilkan laba.

Penelitian mengenai CAR, LDR, dan ukuran perusahaan pada profitabilitas pernah diteliti oleh beberapa peneliti sebelumnya. Hasil penelitian yang dilakukan Akhtar et al. (2011), Suardita \& Putri (2015) menyatakan bahwa CAR berpengaruh positif terhadap ROA, namun berbeda dengan penelitian Alper \& Anbar (2011), serta Negara \& Natalia (2016) yang menunjukkan bahwa CAR berpengaruh negatif terhadap ROA. Hasil penelitian yang dilakukan oleh Almazari (2014), dan Purnamawati (2014) memperlihatkan bahwa LDR berpengaruh positif terhadap ROA, namun pada penelitian Majidi (2017) menyatakan bahwa variabel LDR berpengaruh negatif terhadap ROA.

Berdasarkan penelitian Ogboi \& Unuafe (2013), Septiarini \& Ramantha (2014) menunjukkan bahwa NPL berpengaruh negatif terhadap ROA, tetapi pada penelitian Oktaviantari \& Wiagustini (2013) menunjukkan bahwa NPL berpengaruh positif terhadap ROA. Hasil penelitian Febrianti (2012) dan Yatiningsih \& Chabachib (2015) menunjukkan ukuran perusahaan berpengaruh positif terhadap ROA, tetapi pada penelitian Said \& Tumin (2011), Niresh \& Velnampy (2014) menyebutkan bahwa ukuran perusahaan berpengaruh negatif terhadap ROA.

Adanya ketidakkonsistenan pada hasil penelitian sebelumnya, maka peneliti menggunakan pendekatan kontingensi yaitu risiko kredit sebagai pemoderasi. Alasan peneliti memilih risiko kredit yang menjadi variabel moderasi dikarenakan dalam menyalurkan kredit, bank tidak terlepas dari adanya risiko kredit, sehingga dapat diduga jika risiko kredit tinggi maka akan berdampak pada kecukupan modal, penyaluran kredit, dan ukuran perusahaan sehingga ROA bank menurun. Maka dari itu perlu dilakukan penelitian kembali dengan menambahkan variabel moderasi yaitu risiko kredit yang diduga mampu memperkuat atau memperlemah hubungan antara variabel tersebut.

Kecukupan modal adalah ukuran yang menentukan jika bank memiliki modal yang memadai yang menawarkan perlindungan terhadap risiko yang terkait dengan penawaran kredit bank dan usaha keuangan lainnya. Kecukupan modal dalam penelitian ini diproksikan melalui Capital Adequacy Ratio (CAR). CAR merupakan indikator terhadap kemampuan bank untuk menutupi penurunan aktivitas sebagai akibat dari kerugian-kerugian bank yang disebabkan oleh aktiva berisiko. Semakin besar rasio CAR, maka semakin rendah kemungkinan timbulnya bank bermasalah dan juga dapat meningkatkan kepercayaan terhadap masyarakat. Dengan semakin rendah kemungkinan timbulnya bank bermasalah, maka semakin besar pula tingkat profitabilitas suatu bank.

Hal ini sesuai dengan penelitian yang dilakukan oleh Ndifon \& Ojong (2014), dan Purnamawati (2014) yang menyatakan bahwa rasio CAR 
berpengaruh positif terhadap profitabilitas bank. Berdasarkan uraian tersebut, maka peneliti merumuskan hipotesis sebagai berikut.

$\mathrm{H}_{1}$ : Kecukupan modal berpengaruh positif pada profitabilitas.

Sebagai salah satu kegiatan utama bank dan penghasil pendapatan bank, penyaluran kredit ini sifatnya begitu penting sehingga ketika penyaluran kredit menurun akan dapat mempengaruhi kinerja bank. Penyaluran kredit dilakukan dengan menggunakan dana yang didapatkan dari masyarakat dalam bentuk simpanan. Dari penyaluran kredit, bank dapat menghasilkan keuntungan tetapi risiko bank yang terbesar juga bersumber dari pemberian kredit. Loan to deposit ratio (LDR) merupakan rasio perbandingan antara seluruh kredit yang diberikan bank dengan dana yang diterima oleh bank. Semakin tinggi LDR maka semakin tinggi dana yang disalurkan ke dana pihak ketiga. Dengan penyaluran dana pihak ketiga yang besar, maka pendapatan bank akan semakin meningkat.

Pada penelitian yang dilakukan oleh Almazari (2014), serta Negara \& Sujana (2014) menyatakan bahwa tingkat penyaluran kredit (LDR) berpengaruh positif pada profitabilitas. Berdasarkan uraian tersebut, maka peneliti merumuskan hipotesis sebagai berikut.

$\mathrm{H}_{2}$ : Penyaluran kredit berpengaruh positif pada profitabilitas.

Risiko kredit merupakan suatu risiko akibat kegagalan atau ketidakmampuan nasabah dalam mengembalikan jumlah pinjaman yang diterima beserta bunganya sesuai jangka waktu yang telah ditentukan. Risiko kredit terjadi ketika bank memberikan pinjaman kepada nasabah sesuai dengan jangka waktu yang telah disepakati, kemudian nasabah tersebut tidak mampu untuk mengembalikan pinjaman yang telah diterimanya pada saat jatuh tempo beserta bunganya, hal itu bisa disebabkan karena kesengajaan maupun tanpa disengaja, seperti nasabah mengalami bencana alam atau bangkrut, jadi otomatis bank terpaksa harus menanggung risikonya. NPL yang tinggi dapat memperkecil penyaluran dana, sehingga berpotensi terhadap kerugian bank. Semakin tinggi rasio ini maka akan semakin buruk kualitas kredit bank yang menyebabkan jumlah kredit bermasalah semakin besar, dan oleh karena itu bank harus menanggung kerugian dalam kegiatan operasionalnya sehingga berpengaruh terhadap penurunan ROA yang diperoleh bank (Kasmir, 2012). Peningkatan kredit macet akan menurunkan pendapatan dan laba, serta kinerja bank dan hal ini akan menimbulkan persepsi buruk bagi investor. Investor kurang tertarik untuk membeli saham milik bank dengan risiko kredit yang tinggi karena akan berpengaruh negatif terhadap profitabilitas.

Hal ini dikuatkan dengan bukti empiris yang dilakukan oleh Purwoko \& Sudiyatno (2013), dan Singh (2015) menunjukkan hasil bahwa NPL berpengaruh negatif terhadap profitabilitas. Berdasarkan uraian tersebut, maka peneliti merumuskan hipotesis sebagai berikut.

$\mathrm{H}_{3}$ : Risiko kredit berpengaruh negatif pada profitabilitas.

Perusahaan dengan ukuran besar relatif lebih stabil dan lebih mampu menghasilkan laba dibandingkan dengan perusahaan kecil. Ukuran perusahaan memiliki pengaruh terhadap profit yang diperoleh pada suatu bank, di mana semakin besar ukuran bank semakin besar kemungkinan profit yang diperoleh. Besar kecilnya ukuran suatu bank akan mempengaruhi kemampuannya dalam menanggung risiko yang mungkin timbul akibat berbagai situasi yang akan 
dihadapi dalam kegiatan perbankan. Teori ini sejalan dengan penelitian Alper \& Anbar (2011), dan Lipunga (2014) yang memiliki hasil bahwa ukuran perusahaan berpengaruh positif terhadap profitabilitas. Berdasarkan uraian tersebut, maka peneliti merumuskan hipotesis sebagai berikut.

$\mathrm{H}_{4}$ : Ukuran perusahaan berpengaruh positif pada profitabilitas.

Semakin tinggi persentase NPL, akan menyebabkan jumlah modal yang dimiliki oleh suatu bank akan berkurang. Hal ini terjadi karena pendapatan yang seharusnya diterima oleh bank menjadi modal yang digunakan untuk menutupi tingginya NPL, sehingga akan mengakibatkan kepercayaan masyarakat terhadap bank tersebut akan semakin berkurang. Maka dari itu, NPL yang tinggi akan mengakibatkan berkurangnya profitabilitas, karena pendapatan bunga yang seharusnya diterima menjadi berkurang. Teori ini sejalan dengan hasil penelitian dari Negara \& Sujana (2014) yang menunjukkan bahwa CAR berpengaruh negatif oleh variabel NPL. Berdasarkan uraian tersebut, maka peneliti merumuskan hipotesis sebagai berikut.

$\mathrm{H}_{5}$ : Risiko kredit berpengaruh negatif pada hubungan antara kecukupan modal dengan profitabilitas.

NPL yang tinggi akan mengakibatkan kerugian pada bank, seperti tidak diterimanya kembali dana yang telah disalurkan dan pendapatan bunga yang harusnya diterima, sehingga bank kehilangan kesempatan mendapatkan bunga, tidak dapat memenuhi kewajiban jangka pendeknya seperti membayar kembali pencairan dana deposannya pada saat ditagih serta tidak dapat mencukupi permintaan kredit yang telah diajukan dan berakibat penurunan pendapatan secara total. Teori tersebut sejalan dengan penelitian yang dilakukan oleh Widiasari (2015), Negara \& Natalia (2016) yang menyatakan NPL berpengaruh negatif terhadap hubungan antara LDR dengan profitabilitas. Berdasarkan uraian tersebut, maka peneliti merumuskan hipotesis sebagai berikut.

$\mathrm{H}_{6}$ : Risiko kredit berpengaruh negatif pada hubungan antara penyaluran kredit dengan profitabilitas.

Semakin besar ukuran perusahaan perbankan yang ditunjukkan dengan kepemilikan total assets yang besar juga memiliki peluang yang lebih besar dalam meningkatkan risiko yang harus ditanggung oleh pihak bank. Perusahaan yang memiliki aset yang tinggi, namun memiliki risiko kredit yang tinggi pula dapat menyebabkan investor akan lebih berhati-hati dalam mengivestasikan dananya sehingga berdampak pada penurunan profitabilitas. Teori ini sejalan dengan hasil penelitian Permatasari et al. (2017) bahwa risiko kredit memiliki pengaruh negatif pada ukuran perusahaan terhadap profitabilitas. Berdasarkan uraian tersebut, maka peneliti merumuskan hipotesis sebagai berikut.

$\mathrm{H}_{7}$ : Risiko kredit berpengaruh negatif pada hubungan antara ukuran perusahaan dengan profitabilitas.

\section{METODE PENELITIAN}

Pendekatan pada penelitian ini menggunakan pendekatan kuantitatif. Penelitian ini bertujuan untuk mengetahui profitabilitas dengan menganalisis risiko kredit sebagai pemoderasi hubungan antara rasio kecukupan modal, penyaluran kredit, dan ukuran perusahaan. Penelitian ini dilakukan di Bursa Efek Indonesia (BEI) melalui situs resminya (www.idx.co.id) 
Obyek dalam penelitian ini adalah profitabilitas. Penelitian ini menggunakan tiga jenis variabel yaitu variabel bebas, terikat, dan moderasi. Variabel bebas pada penelitian ini adalah kecukupan modal yang diproksikan dengan Capital Adequacy Ratio (CAR), penyaluran kredit diproksikan dengan Loan to Deposit Ratio (LDR), dan ukuran perusahaan yang diproksikan dengan Firm Size. Variabel terikat pada penelitian ini adalah profitabilitas yang diproksikan dengan Return on Assets (ROA). Variabel moderasi pada penelitian ini adalah risiko kredit yang diproksikan dengan Non Performing Loan (NPL).

Populasi dalam penelitian ini adalah seluruh bank yang terdapat di Bursa Efek Indonesia tahun 2017 yaitu 43 bank. Pengambilan sampel dalam penelitian ini menggunakan teknik purposive sampling, yaitu teknik penentuan sampel dengan pertimbangan tertentu (Sugiyono, 2012:122) sehingga jumlah sampel yang digunakan sebanyak 39 perusahaan bank selama periode pengamatan.

Kriteria pemilihan sampel penelitian ini disajikan pada Tabel 1.

Tabel 1. Hasil Purposive Sampling

\begin{tabular}{ll}
\hline Kriteria & Jumlah \\
\hline Jumlah bank umum yang terdaftar di BEI tahun 2017 & 43 \\
Bank umum yang tidak menyajikan laporan keuangan tahunan & $(3)$ \\
auditan pada periode 2017 & \\
Bank umum yang tidak memiliki data-data yang lengkap terkait & $(1)$ \\
penelitian & 39 \\
Sampel &
\end{tabular}

Sumber: Data Penelitian, 2019

Teknik analisis data yang digunakan adalah teknik analisis Regresi Linier Berganda menggunakan program Moderated Regression Analysis (MRA). MRA adalah salah satu alat khusus dalam pengujian regresi linear berganda, yang dalam persamaan regresinya terkandung unsur interaksi. Persamaan regresi untuk penelitian ini adalah sebagai berikut:

$$
Y=\alpha+\beta_{1} X_{1}+\beta_{2} X_{2}+\beta_{3} X_{3}+\beta_{4} X_{4}+\beta_{5} X_{1}{ }^{*} X_{3}+\beta_{6} X_{2}{ }^{*} X_{3}+\beta_{7} X_{4}{ }^{*} X_{3}+\varepsilon
$$

Keterangan:

$$
\begin{array}{ll}
\mathrm{Y} & =\text { Return On Asset }(\mathrm{ROA}) \\
\mathrm{X}_{1} & =\text { Rasio Kecukupan Modal } \\
\mathrm{X}_{2} & =\text { Rasio Penyaluran Kredit } \\
\mathrm{X}_{3} & =\text { Rasio Risiko Kredit } \\
\mathrm{X}_{4} & =\text { Ukuran Perusahaan } \\
\mathrm{X}_{1}{ }^{*} \mathrm{X}_{3}= & \text { Interaksi antara Rasio Kecukupan Modal dan Rasio } \\
& \quad \text { Risiko Kredit } \\
\mathrm{X}_{2}{ }^{*} \mathrm{X}_{3} & =\text { Interaksi antara Rasio Penyaluran Kredit dan Rasio Risiko } \\
& \text { Kredit } \\
\mathrm{X}_{4}{ }^{*} \mathrm{X}_{3} & =\text { Interaksi antara Ukuran Perusahaan dan Rasio Risko Kredit } \\
\mathrm{\alpha} & =\text { Konstanta } \\
\beta & =\text { Koefisien regresi berganda } \\
\varepsilon & =\text { Faktor lain yang mempengaruhi variabel Y }
\end{array}
$$

\section{HASIL DAN PEMBAHASAN}

Statistik deskriptif dalam penelitian ini disajikan untuk memberikan informasi terkait tentang karakteristik variabel penelitian antara lain nilai minimum, 
maksimum, rata-rata (mean), dan standar deviasi. Berikut ini hasil statistik deskriptif disajikan dalam Tabel 2.

Tabel 2. Hasil Uji Statistik Deskriptif

\begin{tabular}{llllll}
\hline Variabel & $\mathrm{N}$ & Min. & Maks. & Mean & Std. Deviasi \\
\hline CAR $\left(\mathrm{X}_{1}\right)$ & 39 & 9,19 & 35,21 & 19,5341 & 5,80247 \\
LDR $\left(\mathrm{X}_{2}\right)$ & 39 & 51,57 & 111,07 & 83,8051 & 12,71860 \\
NPL $\left(\mathrm{X}_{3}\right)$ & 39 & 0,05 & 6,20 & 2,2110 & 1,48691 \\
Firm Size & 39 & 27,75 & 34,66 & 31,0854 & 1,97734 \\
$\left(\mathrm{X}_{4}\right)$ & & & & & \\
ROA (Y) & 39 & $-7,47$ & 3,89 & 0,9703 & 1,74361 \\
\hline
\end{tabular}

Sumber: Data Penelitian, 2019

Berdasarkan Tabel 2, dapat dilihat nilai minimum untuk variabel CAR adalah sebesar 9,19 yang berasal dari Bank Pembangunan Daerah Jawa Barat dan Banten Tbk, nilai maksimum sebesar 35,21 yang berasal dari Bank Mestika Dharma Tbk. Nilai mean sebesar 19,5341 dan standar deviasi sebesar 5,80247 yang artinya bahwa nilai mean lebih besar dari standar deviasi sehingga mengindikasikan bahwa data variabel CAR berdistribusi normal.

Variabel LDR memiliki nilai minimum 51,57 yang berasal dari Bank Nationalnobu Tbk, nilai maksimum sebesar 111,07 yang berasal dari Bank Woori Saudara Indonesia 1906 Tbk, hal ini berarti bahwa kredit tertinggi yang disalurkan oleh bank sebesar 111,07 persen. Nilai mean sebesar 83,80 dan standar deviasi sebesar 12,7 yang artinya bahwa nilai mean lebih besar dari standar deviasi sehingga mengindikasikan bahwa data LDR berdistribusi normal.

Variabel NPL memiliki nilai minimum sebesar 0,05 yang berasal dari Bank Nationalnobu Tbk, nilai maksimum sebesar 6,20 yang berasal dari Bank Bukopin Tbk, berarti bahwa perusahaan perbankan di BEI memiliki kredit bermasalah tertinggi sebesar 6,20 persen. Nilai mean sebesar 2,21 dan standar deviasi sebesar 1,48 yang berarti bahwa nilai mean lebih besar dari standar deviasi sehingga mengindikasikan bahwa data NPL berdistribusi normal.

Variabel ROA memiliki nilai minimum sebesar $-7,47$ yang berasal dari Bank MNC Internasional Tbk, nilai maksimum ROA sebesar 3,89 yang berasal dari Bank Central Asia Tbk. Nilai mean sebesar 0,97 dan standar deviasi sebesar 1,97 yang menunjukkan adanya kesenjangan yang cukup besar antara nilai minimum dan maksimum dari variabel ROA.

Variabel Firm Size memiliki nilai minimum sebesar 27,75 yang berasal dari Bank Rakyat Indonesia Tbk, nilai maksimum sebesar 34,66 yang berasal dari Bank Mandiri Tbk. Nilai mean sebesar 31,08 dan standar deviasi sebesar 1,74 yang artinya bahwa nilai mean lebih besar dari standar deviasi sehingga mengindikasikan bahwa variabel ukuran perusahaan berdistribusi normal.

Analisis regresi linier berganda ini bertujuan untuk menguji apakah ada pengaruh antara tingkat kecukupan modal, penyaluran kredit, risiko kredit, dan ukuran perusahaan pada profitabilitas, serta hubungan risiko kredit terhadap tingkat kecukupan modal, penyaluran kredit, dan tingkat ukuran perusahaan pada profitabilitas. Hasil analisis regresi linier berganda yang disajikan pada Tabel 3. 
Tabel 3. Hasil Regresi Linier Berganda

\begin{tabular}{|c|c|c|c|c|c|}
\hline \multirow[t]{2}{*}{ Model } & \multicolumn{2}{|c|}{$\begin{array}{l}\text { Unstandardized } \\
\text { Coefficients }\end{array}$} & \multirow{2}{*}{$\begin{array}{c}\begin{array}{c}\text { Standardized } \\
\text { Coefficients }\end{array} \\
\text { Beta }\end{array}$} & \multirow[t]{2}{*}{$\mathrm{t}$} & \multirow[t]{2}{*}{ Sig. } \\
\hline & $\mathrm{B}$ & Std. Error & & & \\
\hline (Constant) & $-12,093$ & 10,488 & & $-1,153$ & 0,258 \\
\hline $\mathrm{X} 1$ & 0,113 & 0,095 & 0,331 & 1,186 & 0,245 \\
\hline$X 2$ & 0,075 & 0,042 & 0,481 & 1,777 & 0,085 \\
\hline $\mathrm{X} 3$ & $-2,130$ & 5,416 & $-1,601$ & $-0,393$ & 0,697 \\
\hline $\mathrm{X} 4$ & 0,148 & 0,315 & 0,131 & 0,471 & 0,641 \\
\hline X1_X3 & 0,032 & 0,044 & 0,408 & 0,738 & 0,466 \\
\hline $\mathrm{X} 2 \_\mathrm{X} 3$ & $-0,017$ & 0,018 & $-1,053$ & $-0,994$ & 0,328 \\
\hline X4_X3 & 0,096 & 0,150 & 2,212 & 0,642 & 0,525 \\
\hline \multicolumn{6}{|c|}{ Adjusted $R_{\text {square }}: 0,217$} \\
\hline$F_{\text {hitung }}$ & $: 2,505$ & & & & \\
\hline Sig. F Fitung & $: 0,037$ & & & & \\
\hline
\end{tabular}

Sumber: Data Penelitian, 2019

Berdasarkan Tabel 3, dapat disusun persamaan regresi sebagai berikut.

$Y=-12,093+0,113 X_{1}+0,075 X_{2}-2,130 X_{3}+0,148 X_{4}+0,032 X_{1} X_{3}-0,017 X_{2} X_{3}+$ $0,096 \mathrm{X}_{4} \mathrm{X}_{3}$

Hasil analisis statistik untuk variabel kecukupan modal diketahui bahwa koefisien regresi bernilai sebesar 0,113 dengan nilai signifikansi yang dimiliki lebih besar dibanding taraf signifikansi yang telah ditetapkan $(0,245>0,05)$ sehingga dalam hal ini pengaruh rasio kecukupan modal tidak berpengaruh terhadap profitabilitas. Tidak berpengaruhnya CAR terhadap ROA disebabkan karena bank-bank yang beroperasi pada tahun tersebut tidak mengoptimalkan modal yang ada. Ini ditunjukkan dengan rata-rata nilai CAR pada tahun 2017 sebesar 19,5341. Hal ini terjadi karena peraturan Bank Indonesia yang mensyaratkan CAR minimal sebesar 8 persen mengakibatkan bank-bank selalu berusaha agar CAR yang dimilikinya sesuai dengan ketentuan tersebut, dan juga dapat disebabkan karena adanya penambahan modal untuk mengantisipasi perkembangan skala usaha berupa ekspansi kredit atau pinjaman yang diberikan, namun pada kenyataannya sampai saat ini bank belum dapat melempar pinjaman sesuai dengan yang diharapkan atau belum optimal.. Hasil penelitian ini sesuai dengan penelitian yang dilakukan oleh Negara \& Sujana (2014) yang menyatakan bahwa kecukupan modal tidak berpengaruh terhadap profitabilitas.

Hasil yang diperoleh untuk pengaruh LDR terhadap ROA adalah 0,481 dengan nilai signifikansi yang dimiliki lebih besar dibanding taraf signifikansi yang telah ditetapkan $(0,085>0,05)$ yang berarti rasio penyaluran kredit tidak berpengaruh terhadap profitabilitas. Sikap kehati-hatian yang tinggi untuk menghindari risiko kredit bermasalah diduga menjadi penyebab tidak mampunya penyaluran kredit mempengaruhi profitabilitas. Dana yang dimiliki belum dimanfaatkan dengan optimal sehingga belum mampu mempengaruhi profitabilitas. Hasil ini sejalan dengan penelitian Alper \& Anbar (2011) yang menyatakan bahwa rasio penyaluran kredit tidak berpengaruh terhadap profitabilitas.

Hasil analisis statistik untuk variabel risiko kredit diketahui bahwa koefisien regresi sebesar -2,130 dengan nilai signifikansi yang dimiliki lebih besar 
dibanding taraf signifikansi yang telah ditetapkan $(0,697>0,05)$ yang berarti risiko kredit berpengaruh negatif terhadap profitabilitas. Dari data yang diperoleh, NPL perbankan tahun 2017 relatif kecil atau sedikit yang macet, sehingga NPL tidak mempengaruhi profitabilitas bank. Hasil yang sama ditunjukkan oleh Yudiartini \& Dharmadiaksa (2016) yang menyatakan bahwa NPL tidak berpengaruh terhadap ROA. Hal ini dapat dilihat dari nilai NPL relatif rendah, hal ini sangat dimungkinkan bahwa angka kredit macet di bank umum juga rendah.

Hasil analisis statistik untuk variabel ukuran perusahaan diketahui bahwa koefisien regresi sebesar 0,148 dengan nilai signifikansi 0,641 lebih besar dari taraf signifikansi yang telah ditetapkan yaitu 0,05 yang berarti ukuran perusahaan tidak berpengaruh terhadap profitabilitas. Pada kenyataannya, besarnya ukuran suatu perusahaan tidak selalu menentukan besarnya profitabilitas yang diperoleh perusahaan. Seperti yang terjadi dalam penelitian ini di mana ukuran perusahaan tidak berpengaruh pada profitabilitas, hal ini mungkin disebabkan karena tingginya pembiayaan sehingga return yang didapatkan menjadi kecil. Hasil penelitian didukung oleh penelitian sebelumnya yaitu Dietrich \& Wanzenried (2009) yang memberikan hasil ukuran perusahaan tidak berpengaruh terhadap profitabilitas.

Hasil penelitian menunjukkan bahwa hasil koefisien interaksi kecukupan modal dengan risiko kredit sebesar 0,032 dengan tingkat signifikansi sebesar 0,466 yang nilainya lebih besar dari taraf nyata yaitu 0,05 . Berdasarkan data tersebut dapat disimpulkan bahwa risiko kredit tidak dapat memoderasi pengaruh kecukupan modal pada profitabilitas. Belum mampunya risiko kredit mempengaruhi pengaruh kecukupan modal terhadap profitabilitas diduga karena bank yang terdaftar di BEI pada tahun 2017 rata-rata memiliki risiko kredit (NPL) di bawah 5 persen. Tingkat NPL yang masih rendah belum mampu mempengaruhi kecukupan modal (CAR), sehingga tidak mempengaruhi profitabilitas. Hasil penelitian ini sejalan dengan penelitian yang dilakukan oleh Warnayanti \& Dewi (2018) yang menyatakan bahwa NPL tidak mampu memoderasi pengaruh kecukupan modal terhadap profitabilitas.

Hasil penelitian menunjukkan bahwa hasil koefisien interaksi penyaluran kredit dengan risiko kredit sebesar -0,017 dengan tingkat signifikansi sebesar 0,328 yang nilainya lebih besar dari taraf nyata yaitu 0,05 . Berdasarkan data tersebut maka dapat disimpulkan bahwa risiko kredit berpengaruh negatif pada hubungan antara penyaluran kredit dengan profitabilitas. Risiko kredit tidak mempengaruhi hubungan antara penyaluran kredit dengan profitabilitas dikarenakan tingkat risiko kredit (NPL) dari perusahaan perbankan yang terdaftar di BEI tahun 2017 yang rendah yaitu kurang dari 5 persen diduga sebagai penyebab belum mampunyai NPL mempengaruhi penyaluran kredit. Artinya perusahaan perbankan telah mampu mengelola kredit bermasalah yang dimiliki sehingga tidak menimbulkan risiko yang besar terhadap penyaluran kredit. Hasil penelitian ini sejalan dengan penelitian yang dilakukan oleh Negara \& Natalia (2016) yang menyatakan bahwa NPL berpengaruh negatif terhadap hubungan antara LDR dengan profitabilitas.

Hasil penelitian menunjukkan bahwa hasil koefisien interaksi ukuran perusahaan dengan risiko kredit sebesar 0,096 dengan tingkat signifikansi 
sebesar 0,525 yang nilainya lebih besar dari taraf nyata yaitu 0,05. Berdasarkan data tersebut maka dapat disimpulkan bahwa risiko kredit tidak dapat memoderasi pengaruh ukuran perusahaan pada profitabilitas. Hal ini mungkin dikarenakan baik perusahaan besar maupun perusahaan kecil apabila perusahaan tersebut telah mampu meminimalisir risiko kredit yang dimilikinya, maka hal tersebut tidak menyebabkan ukuran perusahaan mempengaruhi profitabilitas perusahaan. Dapat dilihat dari rata-rata nilai NPL yang dimiliki oleh perusahaan perbankan yang terdaftar di Bursa Efek Indonesia, di mana sebagian besar perusahaan perbankan tersebut memiliki nilai NPL yang cukup kecil yaitu kurang dari 5\%. Hal ini mengakibatkan berapapun besar kecilnya perusahaan perbankan yang ada di Indonesia, apabila perusahaan tersebut sudah mampu mengurangi risiko kreditnya maka ukuran perusahaan tersebut tidak akan mempengaruhi profitabilitasnya. Hasil penelitian ini sejalan dengan Niresh \& Velnampy (2014) yang menyatakan bahwa NPL tidak berpengaruh terhadap hubungan antara ukuran perusahaan dengan profitabilitas.

Nilai Adjusted $R^{2}$ sebesar 0,217 memiliki arti bahwa 21,7\% variasi Profitabilitas mampu dijelaskan oleh variabel kecukupan modal, penyaluran kredit, ukuran perusahaan, serta variabel risiko kredit sebagai pemoderasi. Sedangkan sisanya $78,3 \%$ dipengaruhi oleh faktor lain yang tidak diteliti dalam penelitian ini.

Hasil uji $\mathrm{F}$ memperoleh $\mathrm{F}$ hitung sebesar 2,505 dengan signifikansi lebih kecil dari 0,05 $(0,000<0,05)$ sehingga dapat disimpulkan bahwa seluruh variabel mampu memprediksi dan menjelaskan fenomena profitabilitas perusahaan dan model regresi yang digunakan mampu memprediksi pengaruh kecukupan modal, penyaluran kredit, ukuran perusahaan, dan risiko kredit sebagai pemoderasi pada profitabilitas bank umum yang terdaftar pada Bursa Efek Indonesia tahun 2017.

\section{SIMPULAN}

Penelitian ini dapat menjadi suatu hal baru untuk penelitian yang berhubungan dengan variabel kecukupan modal, penyaluran kredit, ukuran perusahaan, risiko kredit, dan profitabilitas. Pengolahan data dilakukan dengan menggunakan Moderated Regression Analysis (MRA) untuk memperkirakan hubungan antara variabel-variabel yang telah ditetapkan sebelumnya berdasarkan teori. Hasil penelitian ini dapat digunakan untuk memperkaya referensi yang berkaitan dengan kecukupan modal, penyaluran kredit, ukuran perusahaan, risiko kredit, dan profitabilitas. Penelitian ini menghasilkan simpulan mengenai risiko kredit sebagai pemoderasi pengaruh kecukupan modal, penyaluran kredit, dan ukuran perusahaan pada profitabilitas.

Hasil dalam penelitian ini diharapkan dapat memberikan informasi mengenai pentingnya meningkatkan profitabilitas agar tidak memberatkan beban operasional bank. Penelitian ini berhasil membuktikan signaling theory yaitu profitabilitas yang tinggi menunjukkan prospek perusahaan baik, sehingga investor akan merespon positif sinyal tersebut dan nilai perusahaan akan meningkat. 


\section{REFERENSI}

Akhtar, M. F., Ali, K., \& Sadaqat, S. (2011). Factor Influencing the Profitability of Islamic Banks in Pakistan. International Research Journal of Finance and Economics, (66), 125-132.

Almazari, A. (2014). Impact of Internal factors on Bank Profitability Comparative Study between Saudi Arabia and Jordan. Journal of Applied Finance $\mathcal{E}$ Banking, 4(1), 125-140.

Alper, D., \& Anbar, A. (2011). Bank Specific and Macroeconomic Determinats of Commercial Bank Profitability: Empirical Evidence from Turkey. Business and Economics Research Journal, 2(2), 139-152.

Dietrich, A., \& Wanzenried, G. (2009). What Determines the Profitability of Commercial Banks? New Evidence from Switzerland. The Journal of Lucerne University of Applied Sciences, 1(1), 1-39.

Febrianti, M. (2012). Faktor - Faktor Yang Mempengaruhi Nilai Perusahaan Pada Industri Pertambangan Di Bursa Efek Indonesia. Jurnal Bisnis Dan Akuntansi, 14(2), 141-156.

Hendra, E. S. (2016). Pengaruh Kecukupan Modal, Risiko Kredit dan Biaya Operasional Terhadap Profitabilitas Bank. E-Jurnal Akuntansi Universitas Udayana, 14(3), 2363-2378.

Kasmir. (2012). Analisis Laporan Keuangan. Jakarta: Rajawali Pers.

Lipunga, A. M. (2014). Determinants of Profitability of Listed Commercial Banks in Developing Countries: Evidence from Malawi. Research Journal of Finance and Accounting, 5(6), 41-49.

Majidi, Z. (2017). Analisis Pengaruh CAR, NPL, dan LDR Terhadap Profitabilitas Pada Perusahaan Perbankan yang Listing di BEI (2014-2016). Jurnal Akuntansi Fakultas Ekonomi Universitas Islam Malang, 6(6), 100-114.

Ndifon, \& Ojong, E. (2014). The Impact of Capital Adequacy on Deposit Money Banks' Profitability in Nigeria. Research Journal of Finance and Accounting, 5(12), 7-15.

Negara, I. P. A. A., \& Sujana, I. K. (2014). Pengaruh Capital Adequacy Ratio, Penyaluran Kredit dan Non Performing Loan pada Profitabilitas. E-Jurnal Akuntansi Universitas Udayana, 9(2), 325-339.

Negara, I. W. S., \& Natalia, N. K. D. (2016). Pengaruh Loan to Deposit Ratio dan Capital Adequacy Ratio Terhadap Profitabilitas Bank Umum Konvensional di Indonesia Tahun 2010-2014 dengan Non Performing Loan Sebagai Pemoderasi. Jurnal Riset Akuntansi, 6(4), 71-78.

Niresh, J. A., \& Velnampy, T. (2014). Firm Size and Profitability: A Study of Listed Manufacturing Firms in Sri Lanka. International Journal of Business and Management, 9(4), 57-64.

Ogboi, C., \& Unuafe, O. K. (2013). Impact of Credit Risk Management and Capital Adequacy on the Financial Performance of Commercial Banks in Nigeria. Journal of Emerging Issues in Economics, Finance and Banking, 2(3), 703-717.

Oktaviantari, L. P. E., \& Wiagustini, N. L. P. (2013). Pengaruh Tingkat Risiko Perbankan Terhadap Profitabilitas Pada BPR di Kabupaten Badung. E-Jurnal Manajemen Universitas Udayana, 2(12), 1617-1633.

Permatasari, A. N., Rahadian, D., \& Yunita, I. (2017). Pengaruh CAR, LDR, 
BOPO, NPL, dan Ukuran Perusahaan Terhadap Profitabilitas (Studi Kasus Pada Bank Umum Swasta Nasional Non Devisa d Indonesia Periode 20122015). E-Proceeding of Management, 4(2), 1296-1303.

Purba, A. G. (2018). Pengaruh Kecukupan Modal, Struktur Modal dan Ukuran Perusahaan Pada Profitabilitas dengan Risiko Kredit Sebagai Pemoderasi. EJurnal Akuntansi Universitas Udayana, 23(2), 1008-1037.

Purnamawati, I. G. A. (2014). The Effect Of Capital And Liquidity Risk To Profitability On Conventional Rural Bank In Indonesia. South East Asia Journal of Contemporary Business, Economics and Law, 5(1), 44-50.

Purwoko, D., \& Sudiyatno, B. (2013). Faktor-Faktor Yang Mempengaruhi Kinerja Bank (Studi Empirik Pada Industri Perbankan Di Bursa Efek Indonesia). Jurnal Bisnis Dan Ekonomi (JBE), 20(1), 25-39.

Said, R. M., \& Tumin, M. H. (2011). Performance and Financial Ratios of Commercial Banks in Malaysia and China. International Review of Business Research Papers, 7(2), 157-169.

Septiarini, N. L. S., \& Ramantha, I. W. (2014). Pengaruh Rasio Kecukupan Modal Dan Rasio Penyaluran Kredit Terhadap Profitabilitas Dengan Moderasi Rasio Kredit Bermasalah. E-Jurnal Akuntansi Universitas Udayana, 7(1), 192206.

Singh, A. (2015). Effect of Credit Risk Management on Private and Public Sector Banks in India. International Journal of Academic Research in Business and Social Sciences, 5(1), 1-11.

Suardita, I. W., \& Putri, I. G. A. . A. D. (2015). Pengaruh Kecukupan Modal dan Penyaluran Kredit Pada Profitabilitas dengan Pemoderasi Risiko Kredit. EJurnal Akuntansi Universitas Udayana, 11(2), 426-440.

Sugiyono. (2012). Metode Penelitian Kuantitatif, Kualitatif, dan RED. Bandung: Alfabeta.

Trisna, A. A. A. (2017). Kualitas Kredit Sebagai Pemoderasi Pengaruh Tingkat Penyaluran Kredit dan Dana Pihak Ketiga Pada Profitabilitas. E-Jurnal Akuntansi Universitas Udayana, 19(3), 2090-2117.

Warnayanti, N. K. A., \& Dewi, S. K. S. (2018). Peran Risiko Kredit dalam Memoderasi Kecukupan Modal, Penyaluran Kredit dan BOPO Terhadap Profitabilitas. E-Jurnal Manajemen Unud, 7(1), 105-133.

Widiasari, N. K. Y. (2015). Pengaruh Loan to Deposit Ratio Pada Profitabilitas Dengan Non Performing Loan Sebagai Pemoderasi. E-Jurnal Akuntansi Universitas Udayana, 10(2), 588-601.

www.idx.co.id.

Yatiningsih, N. F., \& Chabachib, M. (2015). Analisis Pengaruh BOPO, LDR, NPL, SIZE, CAR, dan NIM terhadap ROA. E-Jurnal Manajemen Universitas Diponegoro, 4(3), 1-10.

Yudiartini, D. A. S., \& Dharmadiaksa, I. B. (2016). Pengaruh Rasio Keuangan Terhadap Kinerja Keuangan Sektor Perbankan di Bursa Efek Indonesia. EJurnal Akuntansi Universitas Udayana, 14(2), 1183-1209. 